\title{
Sperm Cells as Vectors in the Production of Transgenic Animals
}

\author{
Rebecca M. Prince
}

April 28, 1993
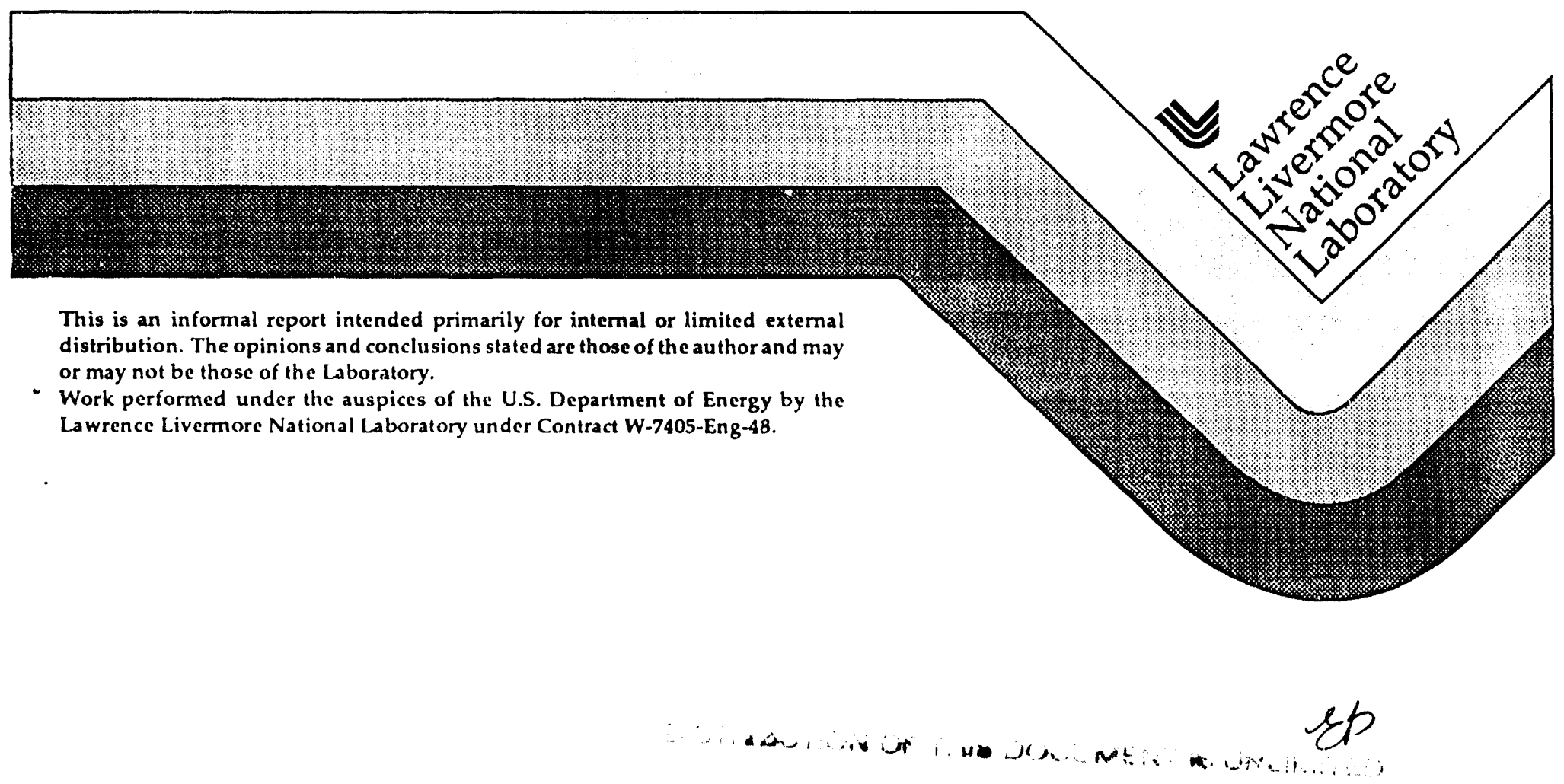


\section{DISCLAIMER}

This document was prepared as an account of work sponsored by an agency of the United States Government. Neither the United States Government nor the University of Califormia nor any of their employees, makes any warranty, express or implied, or assumes any legal liability or responsibility for the accuracy, completeness, or usefuiness of an y information, apparatus, product, or process disclosed, or represents that its use would not infringe privately owned rights. Reference herein to any specific commercial products, process, or service by trade name, trademark, manufacturer, or otherwise, does not necessarily constitute or imply its endorsement, recommendation, or favoring by the United States Government or the University of California. The views and opinions of authors expressed herein do not necessarily state or reflect those of the United States Government or the University of California, and shall not be used for advertising or product endorsement purposes.

This report has been reproduced directly from the best available copy.

Available to DOE and DOE contractors from the Office of Scientific and Technical Information P.O. Box 62, Oak Ridge, TN 37831

Prices available from (615) 576.8401, FTS 626.8401

Avalable to the public from the National Technical Information Service

U.S. Department of Commerce 5285 Port Royal Rd. Springfield, VA 22161 


\title{
SPERM CELLS AS VECTORS IN THE PRODUCTION OF TRANSGENIC ANIMALS
}

\author{
Rebecca M. Prince \\ California State University at Hayward \\ Lawrence Livermore National Laboratory \\ Livermore, California 94550
}

18 December 1992

Prepared in partial fulfillment of the requirements of the Science and Engineering Research Semester under the direction of Rod Balhorn and Nicholas Hud, Research Mentors, in the Lawrence Livermore National Laboratory.

*This research was supported in part by an appointment to the U.S. Department of Energy Science and Engineering Research Semester (hereinafter called SERS) program administered by LLNL under Contract W7405-Eng-48 with Lawrence Livermore National Laboratory. 


\title{
Sperm Cells as Vectors in the Production of Transgenic Animals
}

\author{
Rebecca M. Prince
}

\section{ABSTRACT}

Transgenic animals are used in industry and in biomedical research in order to provide in vivo experimental model systems. Sperm cells have been reported used as vectors in the production of transgenic animals before, however no approach has of yet proven to be successful. Fertilizing eggs with genetically modified sperm would be advantageous in that sperm are readily accessible and stable, and eggs can be fertilized by modified sperm cells in vivo. Recent elucidations regarding the unique manner of DNA packaging in sperm chromatin by protamines has provided us with the insight for developing a method of introducing foreign DNA into sperm which is likely to succeed where others have failed.

We have developed a method for mimicking the in vivo system of sperm chromatin toroiu subunits in vitro, concentrating these toroids, and fluorescent visualization. Our present work concerns development of a method to successfully deliver DNA across the cell membranes and into the nucleus. 


\section{Introduction}

Transgenic animals are used as biomedical research tools to provide in vivo model systems in the study of gene regulation, development, pathogenesis and disease treatment. There are also applications for their use in industry in terms of pharmaceuticals and genetically superior livestock production. The most commonly used method of microinjection is considered to be the most efficient in the production of transgenics (Brinster et al 1985). This laborious method involves several labor intensive, invasive steps that are traumatic to the embryo (Merlino, 1991).

Several laboratories are investigating the possibility of producing transgenic animals using sperm cells as the vector as this appears to be a much more attractive method. Sperm cells are far more readily accessible and stable than eggs, and eggs can be fertilized by modified sperm cells via noninvasive artificial insemination. However, groups working with the development of this hypothesis have not proven to have produced transgenic animals using transformation methods such as simple incubation (Brackett et al, 1971; Lavitrano et al, 1989). The results from these groups indicate that DNA introduced to the cells associates with the cell membranes instead of proceeding with the sperm nucleus into the egg (Atkilson, 1991). Other groups have tried to transform sperm cells using electroporation (Gagné et al, 1991), and liposomal delivery (Bachiller et al, 1991). Bachiller concluded that the foreign [naked] DNA was degraded in the egg cytoplasm by intense enzymatic activity. 
It is proposed that the fundamental packing unit of sperm chromatin is a toroidal structure consisting of DNA highly condensed by protamine (Hud et al, 1992). When DNA is complexed with protamine, enzymatic processes are inhibited (Balhorn, 1990). If a synthesized toroid containing a gene of interest were to be transfected into a sperm cell, it should be indistinguishable from the native sperm chromatin and be protected from enzymatic degradation in the egg cytoplasm.

\section{Materials and Methods}

Labeling of fish protamine toroids

We purchased high purity salmon protamine (salmine grade $X$ ) from Sigma Chemical Co. (St. Louis, MO). Salmine was dissolved at $1 \mathrm{mg} / \mathrm{ml}$ in $100 \mathrm{mM}$ $\mathrm{NaCl} 10 \mathrm{mM}$ Tris $\mathrm{pH}$ 7. Fluorescein isothiocyanate (FITC, Sigma) was dissolved at $10 \mathrm{mg} / \mathrm{ml}$ in methanol (Johnson et al, 1982). $200 \mu \mathrm{g}$ of FITC solution per milligram protein was added to the dissolved protamine (Fig. 1). This solution was incubated at room temperature under darkness conditions for three hours and dialyzed against $100 \mathrm{mM} \mathrm{NaCl}, 10 \mathrm{mM}$ Tris pH 7 to remove excess FITC from the solution.

\section{Synthesizing salmon toroids}

Toroids were synthesized by combining calf thymus DNA (Worthington Biochemical Corporation, Freehold, NJ) with the labeled salmine.

Nonprecipitating concentrations were obtained by combining equal volumes of equal concentrations of DNA and protamine up to a final concentrations of $40 \mu \mathrm{g} / \mathrm{ml}$ in $100 \mathrm{mM} \mathrm{NaCl}, 10 \mathrm{mM}$ Tris $\mathrm{pH} 7$. All samples were imaged with a Zeiss Axioscop. 


\section{Sperm collection and preparation}

Rabbit semen was obtained from healthy, mature, New Zealand white bucks by use of an artificial vagina and a teaser female (Hartman et al, 1974). Sperm were washed twice in a $305 \mathrm{mOsm} / \mathrm{kg}$ defined media as previously described by Brackett et al (1974). For visualizing sperm cells, cells were mounted with propidium iodide (PI) in AntiFade (Johnson et al, 1981).

\section{Electroporation}

Washed sperm cells were subjected to a variety of parameters using the CellPorator electroporation system (Gibco-BRL). The capacitance ranged from 10 to $1980 \mu \mathrm{F}$. The resultant electrical fields applied ranged from 125 to 1062.5 $\mathrm{V} / \mathrm{cm}(\mathrm{d}=0.4 \mathrm{~cm})$. Fields were applied one, two and three times to suspensions containing sperm, sperm with labeled salmine, and sperm with toroids. Parallel controls were prepared using no electroporation. All electroporations were accomplished on ice as described (Potter et al, 1992) in pre-cooled disposable micro-electroporation chambers (Gibco-BRL). The effect on motility was observed before and after electroporation (Gagné et al, 1991). Post-electroporation washes were performed with Brackett's defined media.

\section{Labeling bull toroids}

Bull protamine was isolated as previously described (Balhorn et al., 1977). We reduced the protamine at $1 \mathrm{mg} / \mathrm{ml}$ in $100 \mathrm{mM} \mathrm{NaCl}, 10 \mathrm{mM}$ Tris pH 7 with 10 $\mathrm{mM}$ dithiothreitol (DTT) overnight under a nitrogen atmosphere. FITC was dissolved at $10 \mathrm{mg} / \mathrm{ml}$ in methanol. $200 \mu \mathrm{g}$ of FITC solution per milligram protein was added to the dissolved protamine. This solution was incubated at room temperature under darkness conditions for three hours and dialyzed 
against $100 \mathrm{mM} \mathrm{NaCl}, 10 \mathrm{mM}$ Tris $\mathrm{pH} 7$ to remove excess FITC from the solution. It was then centrifuged to remove any insoluble precipitated FITC.

Synthesizing salt-stable, concentrated bull toroid solution

$27 \mathrm{ml}$ of $20 \mu \mathrm{g} / \mathrm{ml}$ calf thymus DNA and $27 \mathrm{ml}$ of $20 \mu \mathrm{g} / \mathrm{ml}$ bull protamine were combined in $100 \mathrm{mM} \mathrm{NaCl} 10 \mathrm{mM}$ Tris pH $6.54 \mathrm{ml}$ of $100 \mathrm{mM} \mathrm{NaCl} 50$ $\mathrm{mM}$ Tris $\mathrm{pH} 10$ was added and the solution allowed to incubate at room temperature five to seven minutes. $108 \mathrm{ml}$ of $100 \mathrm{mM} \mathrm{NaCl} 100 \mathrm{mM}$ Bis Tris (Sigma) was added then to the solution. $\mathrm{NaCl}$ was added to a final concentration of $2 \mathrm{M}$. To each of six thin-wall polyallomer ultracentrifuge tubes was distributed thirty-five $\mathrm{ml}$ of the above solution. The tubes were centrifuged for 20 minutes at 25,000 rpm (Beckman L8-50M ultracentrifuge with SW-28 rotor). The upper $30 \mathrm{ml}$ from each tube was removed and the lower aliquots vigorously mixed and pooled into one tube. This was centrifuged at $25,000 \mathrm{rpm}$ for 40 minutes. The upper $25 \mathrm{ml}$ was removed and the lower aliquot vigorously mixed to remove any toroids from the sides of the tube.

Some concentrated samples were lyophilized and resuspended in water.

Results

Fluorescent visualization of toroids

When salmine was labeled with FITC, complexed with calf thymus DNA at a final concentration of $40 \mu \mathrm{g} / \mathrm{ml}$ or lower, and placed on a slide under excitation by wavelengths in the blue range, discrete point sources of ye!low green light are observed with a constant green background. Control slides 
with labeled protamine alone exhibit no points of light but instead a constant green background. DNA and salmine complexed to final concentrations greater than $40 \mu \mathrm{g} / \mathrm{ml}$ exhibited points of light and large aggregates.

Toroids synthesized from bull protamine and calf thymus DNA (Fig. 3) appeared identical to those synthesized from salmine with the exception that aggregates appeared as the final solution reached concentrations greater than $10 \mu \mathrm{g} / \mathrm{ml}$ (Fig. 2). However, we observed that toroids subjected to the $\mathrm{pH}$ swing for salt stability exhibited a density on a slide many times that of the initial solution. The constant green background was absent (Fig. 4). The calculated theoretical concentration of toroids concentrated in this method is $108 \mu \mathrm{g} . \mathrm{ml}$ assuming complete recovery. Like the other toroid solutions described, this aggregates over a period of hours as well.

The lyophilized, salt-stable toroids resuspended well in water; we observed fields of point sources more dense than when initially concentrated on slides of them, corresponding to the amount of water the lyophilized product was resuspended in.

Sperm collection and preparation

The sperm cells retained a high percentage of motility after being allowed to sit on a desk top over a period of 48 hours after being washed as described above. Cells visualized under blue excitation after mounting in PI-AntiFade appear are seen as red sperm heads with barely visible tails. 


\section{Electroporation}

The percentage of motile sperm subjected to a $10 \mu \mathrm{F}, 1062.5 \mathrm{~V} / \mathrm{cm}$ field was equal to that of non-electroporated controls. However, approximately $50 \%$ of the cells appeared contorted and approximately $10 \%$ appeared to have undergone the acrosome reaction after receiving three pulses of the same voltage at $800 \mu \mathrm{F}$ capacitance.

Approximately $50 \%$ of cells subjected to a $1180 \mathrm{mF}, 875 \mathrm{~V} / \mathrm{cm}$ field in a suspension of Brackett's media containing toroids were observed to have fluorescent greenish-yellow point sources associated with their cell membranes. Approximately $0.1 \%$ of cells that had not been electroporated but incubated with toroids exhibited this fluorescence. $100 \%$ of cells incubated or electroporated in suspension with only labeled salmine exhibited bright yellow-green fluorescence over their entire membranes. In order to determine whether the point sources were outside or underneath the membrane, the cells were serially washed. After three washings, approximately $5 \%$ of those cells previously exhibiting fluorescence retained this property to some degree.

The density of fluorescent point sources on slides made from aliquots from the chambers after the post-pulse incubation was observed to be less than the predicted density.

\section{Discussion}

Other groups have attempted and failed to produce transgenic animals using sperm cells as vectors. The successful genetic alteration of spermatozoa intended to be used in the generation of transgenic animals can only be 
accomplished. by packaging foreign DNA in such a way that it mimics the in vivo system. In sperm chromatin, the genetic material is packaged into high density units. These toroids can be synthesized in vitro and fluorescently labeled.

The method for toroid concentration was arrived at by studying the molecular structure of protamine (Fig. 5). Toroids can be concentrated through the $\mathrm{pH}$ swing procedure which operates on the principle that cysteines can be manipulated by altering the $\mathrm{pH} ; \mathrm{pKa}$ cysteine=8.3 (Fig. 6). The observed insoluble aggregates are the result of cysteines making disulfide bridges between neighboring toroids made from mammalian protamine in solution. The interior of a toroid benefits from these disulfide bridges in that they give the structure stability, in fact they are stable in $2 \mathrm{M} \mathrm{NaCl}$. As we complex DNA and reduced protamine at a pH less than 7.3, toroids still form because of the electrostatic attraction between the phosphodiester backbone of DNA and the arginines of protamine. However, the cysteines are reduced and do not disulfide bond. As we change the $\mathrm{pH}$ of the solution to 9.3, cysteine loses its proton and is available for disulfide bonding. The bridges form between neighboring cysteines in the toroid's interior, but as the solution is kept very dilute, there is very little chance of one toroid bumping into another and bonding. When the $\mathrm{pH}$ is changed to neutral, the outer cysteines are protonated and therefore prevented from disulfide bonding (Balhorn et al, 1992). This procedure works as we have seen after concentration.

FITC-labeled toroids and PI-lableled sperm are readily distınguishable under blue excitation as point sources of yellow green light and red sperm heads, 
respectively. We have observed that when sperm are electroporated with varying parameters of voltage and capacitance that toroids will appear to associate with the cells. However, $95 \%$ or more toroids are removed when cells are washed, indicating that toroids are only transiently adhered to the outer membrane.

Also, toroids are very dense structures which we propose sink to the bottom of the chamber instead of diffusing through pores created by electroporation. Therefore, electroporation would not be the ideal tool for delivering packaged DNA through the membranes to the sperm nucleus. We are presently looking into a liposomal delivery system.

\section{Acknowledgments}

Thanks so much to Rod Balhorn, Nick Hud, Joe Mazrimas, Shelley Corzett, Joe Lee, and Jeff Ferguson for their as of yet undying patience and a wonderful introduction to scientific research. 


\section{References}

Atkinson, P.W., E.R. Hines, S. Beaton, K.I. Matthaei, K.C. Reed, and M.P. Bradley. Association of exogenous DNA with cattle and insect spermatozoa in vitro. Molec. Reprod. Dev. 29:1-5.

Bachiller, D., K. Schellander, J. Peli, and U. Rüther. 1991. Liposome-mediated DNA uptake by sperm cells. Mol. Reprod. Deo. 30:194-200.

Balhorn, R. 1990. Mammalian protamines: structure and molecular interactions. In Molecular Biology of Chromosome Function. K. Adolph, editor. Springer-Verlag, New York. 366-395.

Balhorn, R., B.L. Gledhill, and A. Wyrobek. 1977. Mouse sperm chromatin proteins: quantitative isolation and partial characterization. Biochem. $16: 4074-4080$.

Balhorn, R., M. Corzett, and J.A. Mazrimas. 1992. Formation of intraprotamine disulfides in vitro. Arch. Biochem. and Biophys. 296:384-393.

Brackett, B.G. and G. Oliphant. 1975. Capacitation of rabbit spermatozoa in vitro. Biol. Rep. 12:260-274.

Brackett, B.G., W. Baranska, W. Sawicki, and H. Koprowski. 1971. Uptake of heterologous genome by mammalian spermatozoa and its transfer to ova through fertilization. Proc. Nat. Acad. Sci. 68:353-357. 
Brinster, R.L., H.Y. Chen, M.E. Trumbauer, M.K. Yagle, and R.D. Palmiter. 1985. Factors affecting the efficiency of introducing foreign DNA into mice by microinjecting eggs. Proc. Natl. Acad. Sci. USA. 82:4438-4442.

Gagné, M.B., J. Pothier, and M. Sirard. 1991. Electroporation of bovine spermatozoa to carry foreign DNA in oocytes. Mol. Reprod. Deo. 29:6-15.

Hartman, H.A. 1974. The fetus in experimental teratology. In The Biology of the Laboratory Rabbit. S.H. Weisbroth, R.E. Flatt, and A.L. Kraus, editors. Academic Press, New York. p.97.

Hud, N.V., M.J. Allen, K. Downing, and R. Balhorn. 1992. How DNA is organized in mammalian sperm cells by protamine. Submitted for publication.

Johnson, G.D., and G.M. de C. Nogueira Araujo. 1981. A simple method of reducing the fading of immunofluorescence during microscopy. J. Imm. Methods. 43:349-350.

Johnson, P. and P.B. Garland. 1982. Fluorescent triplet probes for measuring the rotational diffusion of membrane proteins. Biochem J. 203:313-320.

Lavitrano, M., A. Camaioni, V.M. Fazio, S. Dolci, M.G. Farace, and C. Spadafora. 1989. Sperm cells as vectors for introducing foreign DNA into eggs: genetic transformation of mice. Cell. 57:717-723. 
Merlino, G..T.. 1991. Transgenic animals in biomedical research. FASEB J. 5:2996-3001.

Potter, H. and S.W.F. Cooke. (1992). Gene transfer into adherent cells growing on microbeads. In Guide to Electroporation and Electrofusion. D.C. Chang, B.M. Chassy, J.A. Saunders, and A.E. Sowers, editors. Academic Press, New York. p202.

Smith, L.M., R.J. Kaiser, J.Z. Sanders and L.E. Hood. 1987. The synthesis and use of fluorescent oligonucleotides in DNA sequence analysis. Meth. Enzym. 155:260-301. 


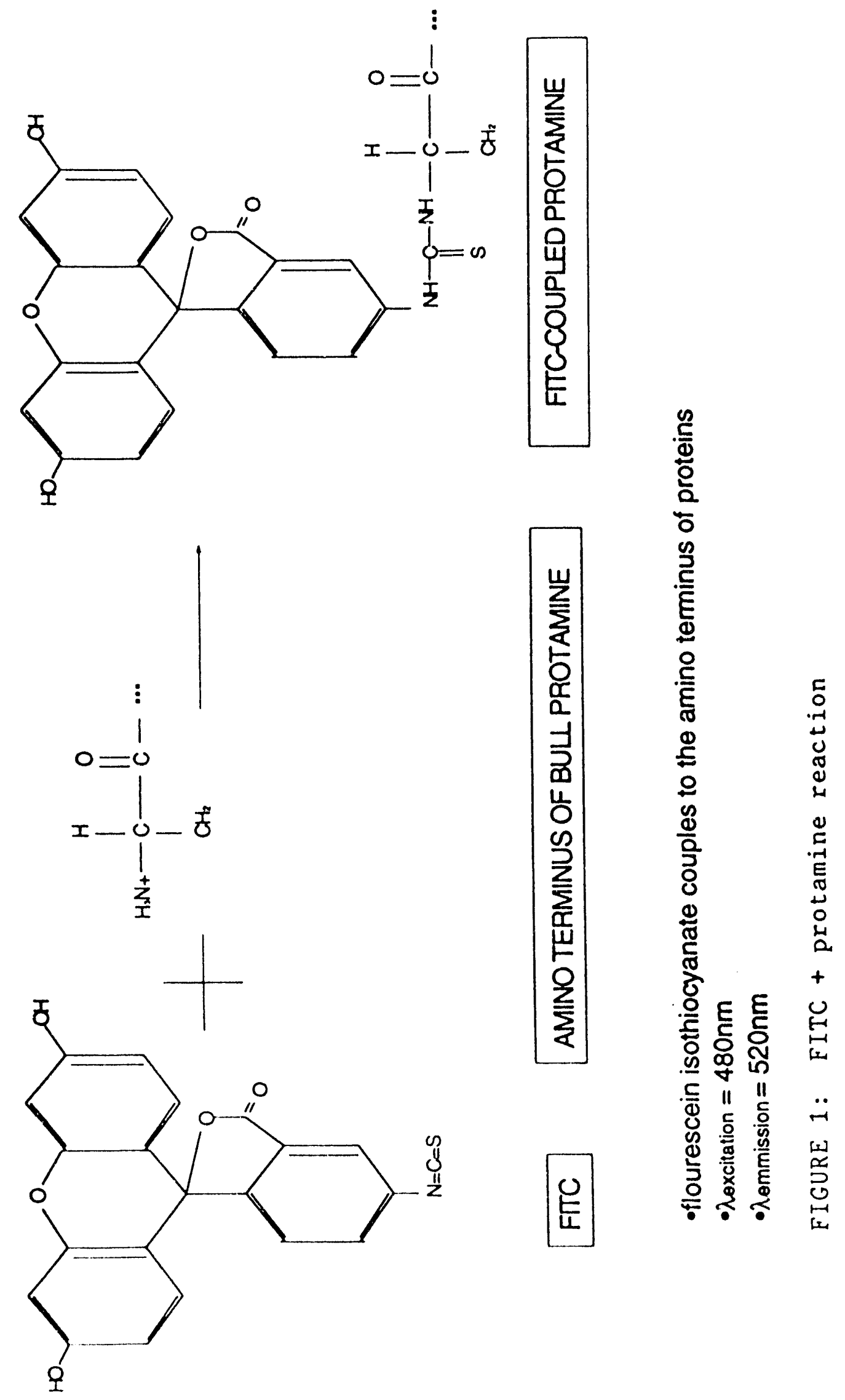




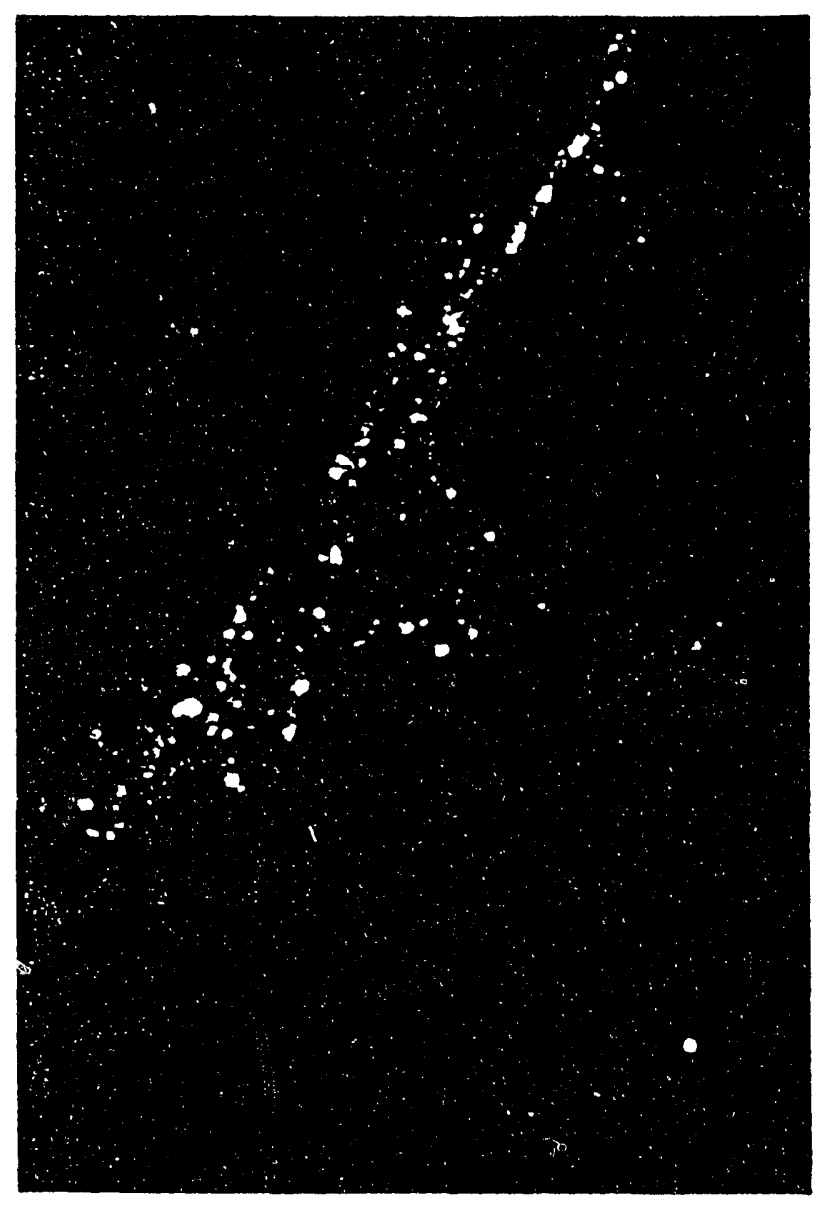

FIGURE 2: aggregate - $15 \mathrm{ug} / \mathrm{ml}$ 


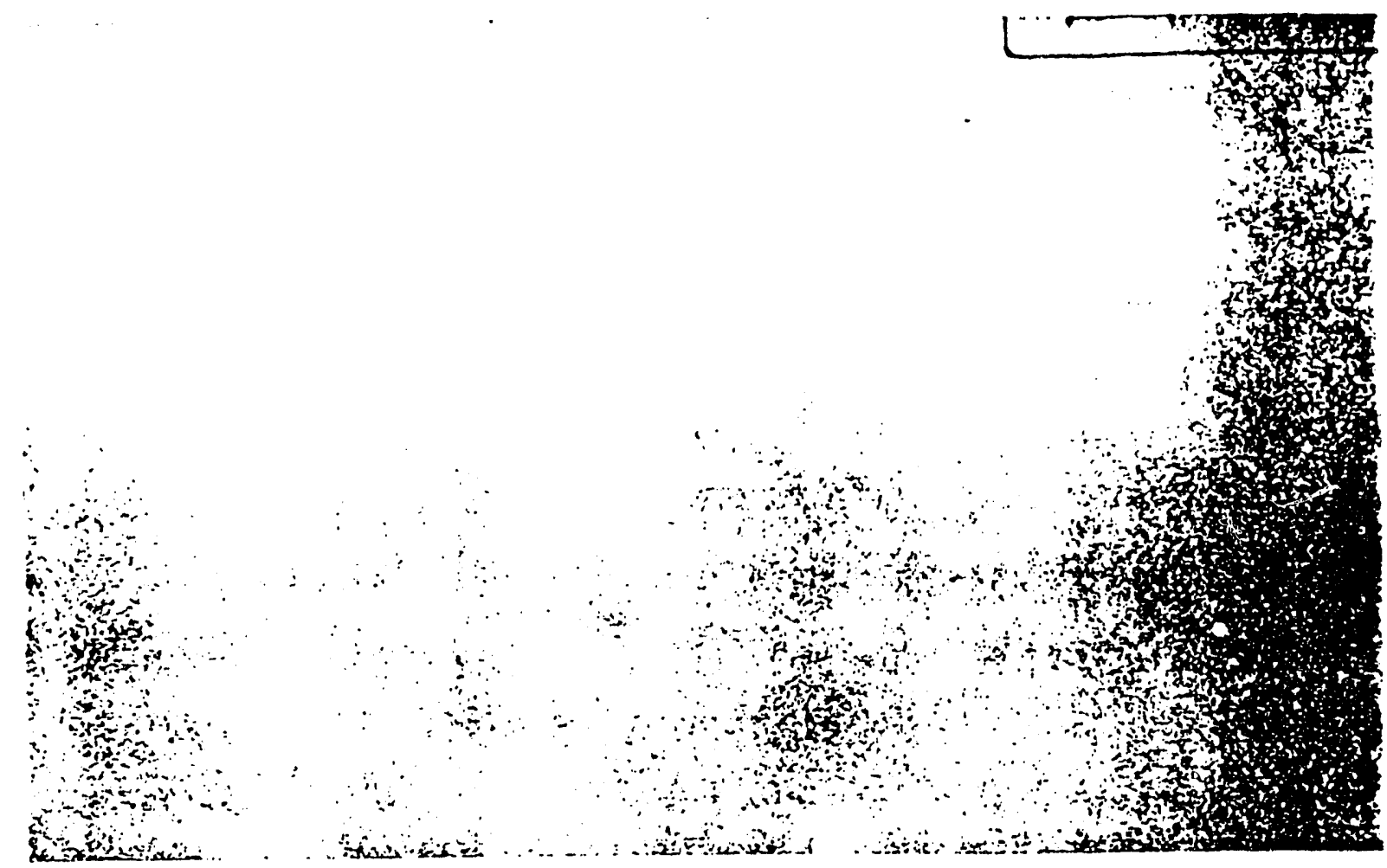

FIGURE 3: $10 \mathrm{ug} / \mathrm{ml}$ toroids

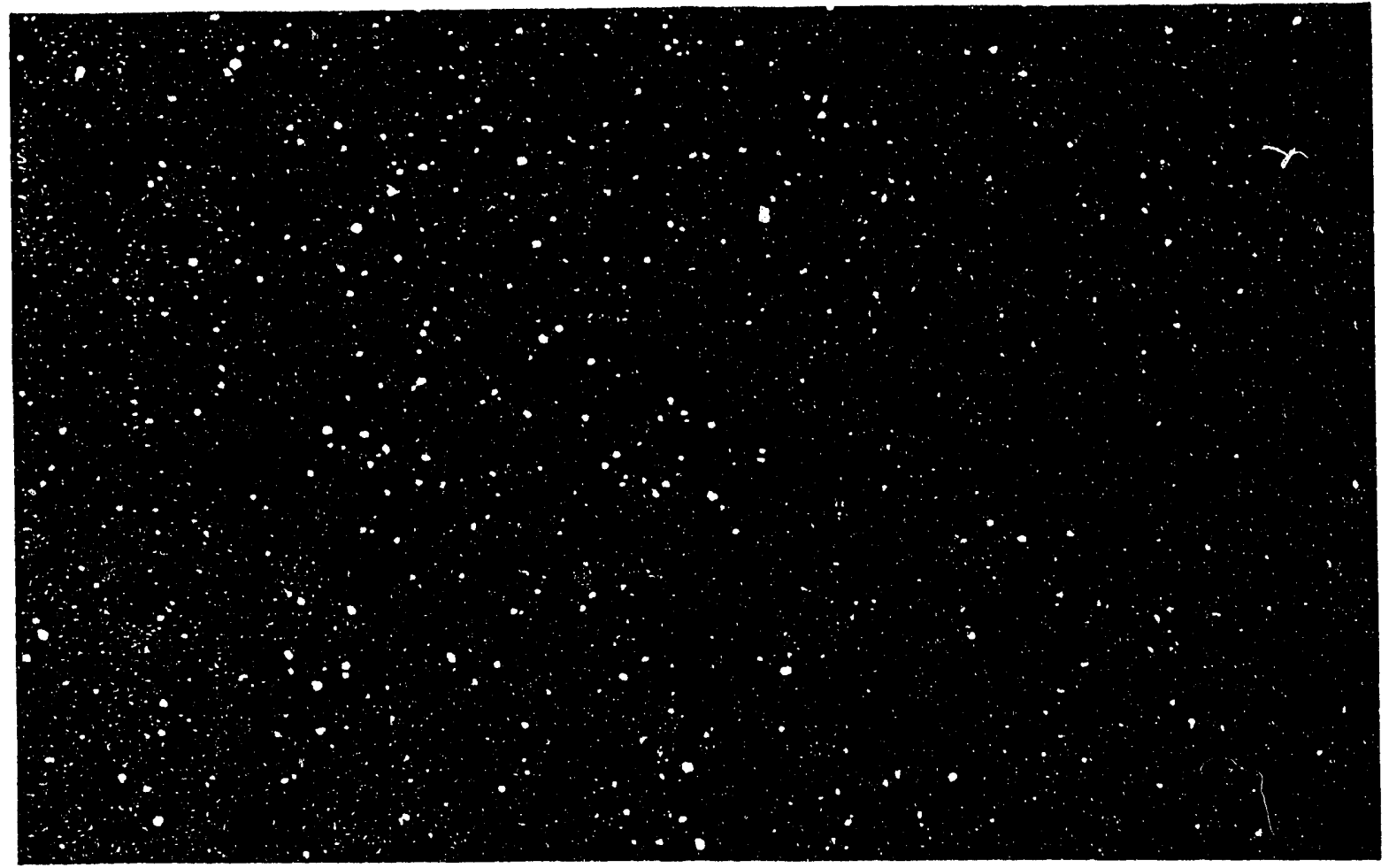

FIGURE \&: $100 \mathrm{ug} / \mathrm{ml}$ toroids 


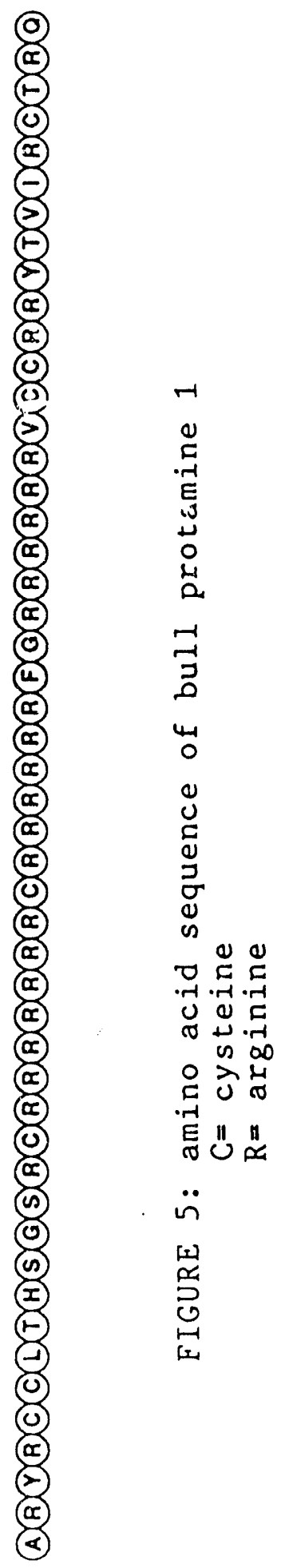




\section{FIGURE 6 \\ Concentrating Toroids by Manipulating Cysteine Sulfhydryls}

- $p K$ acysteine $=8.3$

-at $\mathrm{pH} 8.3$, there is a $1: 1$ equilibrium between these two forms:

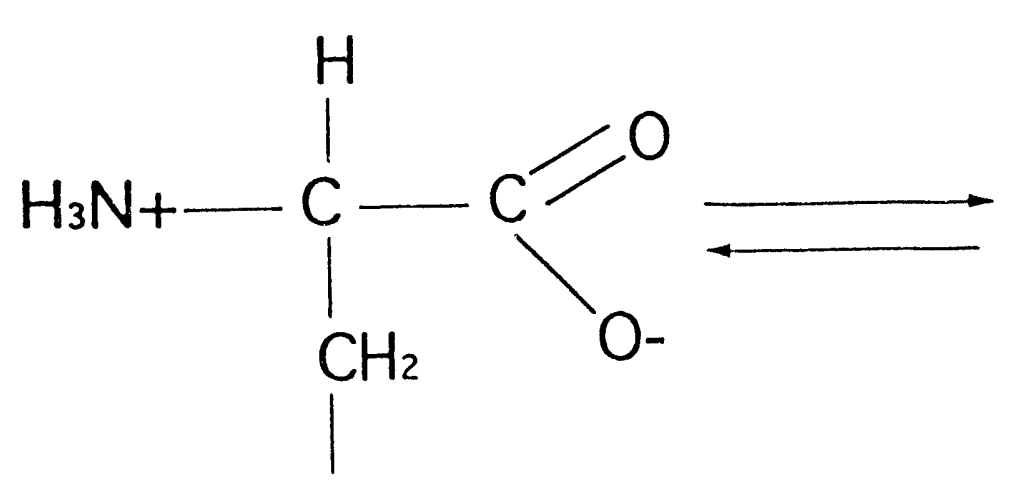

$\mathrm{SH}$

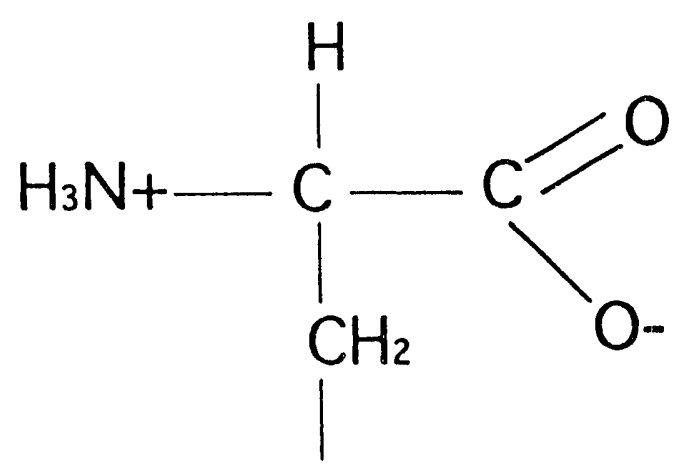

S-
- Favored 10:1 at $\mathrm{pH} 7.3$

- Cannot form disulfide bonds
- Favored 10:1 at pH 9.3 - Ready to form disulfide bonds 

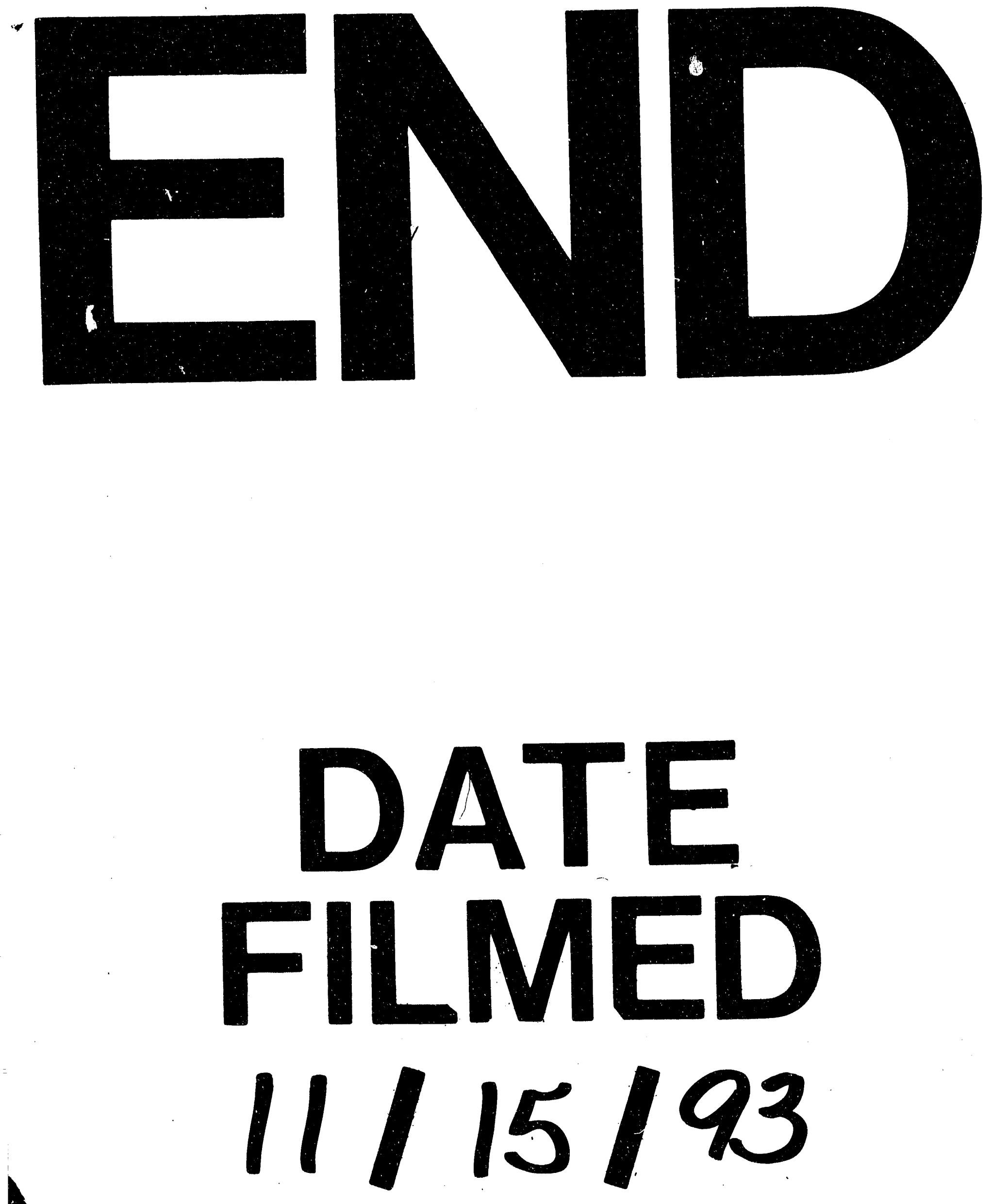
